LANA, MM; MOITA, AW. 2019. Visual quality and waste of fresh vegetables and herbs in a typical retail market in Brazil. Horticultura Brasileira 37: 161-171 DOI - http://dx.doi.org/10.1590/S0102-053620190206

\title{
Visual quality and waste of fresh vegetables and herbs in a typical retail market in Brazil
}

\author{
Milza M Lana1 ${ }^{\mathbb{D}}$; Antônio W Moita1 ${ }^{1 \mathbb{D}}$ \\ ${ }^{1}$ Embrapa Hortaliças, Brasília-DF, Brazil; milza.lana@embrapa.br (correspondence author)
}

\begin{abstract}
Because of high perishability, leafy vegetables and fresh herbs are transported to the market soon after harvest. It is very likely that most of the damage due to inadequate handling at the farm and during transport will result in food discard only later in the retail market or in the household. Inadequate handling and marketing strategies in the store are expected to further contribute to waste. The study was designed to address the following questions: 1 ) what is the visual quality of leafy vegetables and fresh herbs received in the retail market; 2) what is the volume of discard of this produce in the retail market 3) what are the main causes of discard and 4) how these variables are influenced by the vegetable species, the suppliers and the stores evaluated. The study was conducted in 4 stores of a regional supermarket chain in Federal District, Brazil, for a period of 6 months. We evaluated: 1) number of produce items received and discarded;2) visual quality of produce at reception and 3) cause of discard. The operations in each store were described based on observations and discussion with the store staff. When considering the sum of all produce, the discard (expressed as units per day and corrected for quantity purchased) was influenced by all the factors studied, namely store, supplier and day of the week. Delivery of produce with any signs of wilting and yellowing was negligible but produce with bruised and old leaves which should have been trimmed in the farm were frequent. Visual quality was important to determine shelf life and preference by the consumer but how important it was depended on other factors such as the vegetable or herb considered and the workflow in the store. The discard varied from $8.7 \%$ to $97.0 \%$ of the number of units purchased. Smaller waste volume was observed for spring onion, parsley, coriander, collard, leek and green leaf lettuce. Waste volume equal to or above $50 \%$ was observed for baby romaine lettuce, broad-leaved endive, wild chicory, mustard greens, sage and thyme. The vegetables and fresh herbs discard in the Brazilian retail market is in great measure the result of technological constraints together with bad management practices in the store. The implications of this situation for the definitions of food waste and food loss are discussed.
\end{abstract}

Keywords: food wastage, supermarket, visual quality, postharvest handling.

\section{RESUMO}

Qualidade visual e desperdício de hortaliças e ervas frescas em um típico mercado varejista no Brasil

Devido à sua alta perecibilidade, hortaliças folhosas e ervas frescas são transportadas para o mercado logo após a colheita. É de esperar que parte dos danos sofridos durante a colheita e o transporte desses produtos resultem em perda somente nos elos seguintes da cadeia, quais sejam, varejo e consumo. $\mathrm{O}$ manuseio inadequado e $\mathrm{o}$ uso de estratégias de comercialização pouco eficientes no varejo se somam como causas de perda desse grupo de alimentos. O presente estudo foi delineado para responder às perguntas: 1) qual a qualidade visual das hortaliças folhosas e ervas frescas recebidas no mercado varejista; 2) qual o volume de descarte desses produtos no varejo; 3) quais as causas do descarte ; 4) como essas variáveis são influenciadas pela espécie hortícola, fornecedores e lojas avaliadas. O estudo foi realizado em 4 lojas de uma rede regional de supermercados no Distrito Federal, Brasil, pelo período de 6 meses. Foram avaliados: 1) a quantidade de produtos recebidos e descartados na loja; 2) a qualidade visual dos produtos na recepção; 3 ) a causa do descarte; 4) como essas variáveis foram influenciadas pelas espécies hortícolas, fornecedores e lojas avaliadas. As operações em cada loja foram descritas com base em observações e discussão com os funcionários das lojas. Quando se considerou a soma de todos os produtos, o descarte (expresso em número de unidades por dia e corrigido pela quantidade comprada) foi influenciado por todos os fatores, quais sejam, loja, fornecedor e dia da semana. A entrega de produtos murchos e amarelados foi rara, mas eram frequentes os produtos com danos mecânicos e/ou com folhas velhas que deveriam ter sido removidas na colheita. A durabilidade e a preferência do consumidor foram influenciadas pela qualidade visual mas também pela espécie hortícola em questão e pelo fluxo de trabalho na loja. O descarte variou de $8,7 \%$ a $97,0 \%$ do número de unidades compradas. Menor descarte foi observado para cebolinha, salsa, coentro, couve, alho porró e alface crespa. Descarte igual ou superior a $50 \%$ foi observado para alface mini-romana, chicória, almeirão, mostarda, sálvia e tomilho. O descarte de hortaliças folhosas e ervas frescas foi em grande medida resultante de deficiências tecnológicas juntamente com más práticas gerenciais na loja. Os conceitos de perda e de desperdício de alimento face a essa situação são discutidos.

Palavras-chave: Perda e desperdício de alimentos, supermercado, qualidade visual, manuseio pós-colheita.

\section{Received on January 22, 2019; accepted on April 3, 2019}

$T_{0}^{n}$ he Food and Agriculture Organization of the United Nations (FAO) estimates that, on average, one third of all the food produced in the world is discarded before consumption (FAO, 2011). However, significant differences in wastage volume are expected to occur depending on the region, supply chain and food considered. The representation of countries such as Brazil in those estimates is expected to be poor due to lack of data, both because few surveys 
have been conducted in the country and because most of the literature on the subject was published in Portuguese.

In that report, it was also stated that in medium- and high-income countries food is, to a significant extent, wasted at the consumption stage, while in low-income countries food is mostly lost during the early and middle stages of the food supply chain; much less food is wasted at the consumer level. This distinction considers food loss as the discard of food in the early stages of the food supply chain often related with post-harvest activities with lacking system or infrastructural capacities, and food waste as the discard of food mostly at retail and consumer households and often related to human behaviour (Gustavsson et al., 2013).

Brazil is an upper middle-income country according to the World Bank (World..., 2018). In the last decades, the country experienced the modernization of a few vegetable supply chains (Mainville \& Reardon, 2007), a change in the way people buy and consume food (Farina, 2002) and an increased awareness of the importance of vegetables in a healthy diet (Brasil, 2006). In the present, new and old practices of handling and marketing vegetables operate in the country, depending on the region and vegetable species considered. Because of that, it is possible that both food loss and food waste, as defined by FAO, happens in the same supply chain. It is also possible that part of the vegetable discard taking place in the retail market is not related to human behaviour (food waste) but to inadequate post-harvest activities (food loss).

Leafy vegetables and fresh herbs are among the most perishable produce (Bartz \& Brecht, 2003). Their shelflife is much reduced due to wilting and yellowing, which are accelerated under conditions of low air humidity and high temperature. They are also easily bruised. Rough handling causes injuries that compromise visual quality, are entry for pathogens and accelerate wilting and yellowing.

In Brazil, the production of leaf vegetables and fresh herbs is concentrated in areas near the urban centres. Harvest systems are mainly manual and involve a number of operations that results in intense manipulation and damages the produce. Due to their perishability, they are transported to the market soon after harvest and it is very likely that most of the damage caused during harvest, early handling and transport will be visible only in the later stages of the supply chain, namely retail and consumption. At the same time, we know that the produce sector in small supermarket chains do not receive the same attention given to other sectors in the store. Inadequate practices during reception, display and restock, together with the habit of Brazilian consumers to careless handle the produce in display to choose the ones they will buy, are factors expected to further damage the produce and result in their discard. Because of that, we hypothesise that vegetables and fresh herbs discard in the retail market will be the result of both the low quality of the produce received and the poor management of the produce in the store.

The present research addresses the following questions: 1) what is the visual quality of leafy vegetables and fresh herbs purchased by the retail market; 2) what is the volume of discard of leafy vegetables in the retail market and 3) what are the main causes of discard. The study also addresses how these variables are influenced by the vegetable species, the suppliers and the stores evaluated. The research questions were addressed by measuring the discard of leafy vegetables and fresh herbs in a supermarket chain in Federal District, Brazil. Because the research was conducted in the retail sector, we used the term waste, which is the one predominantly used to refer to food discard at this stage of the supply chain. However, for reasons discussed further in this paper, we consider that the food waste reported here includes aspects related to food loss as it is defined by FAO.

\section{MATERIAL AND METHODS}

\section{Study site and plant material}

The study was conducted in four stores of a regional supermarket chain in
Federal District, Brazil. The four stores were chosen from a group of 15 stores to include those that differed in size, volume of sales and customer profile. This type and size of supermarket is very common in the country, both in small and large cities.

All leafy vegetables and fresh herbs sold in the stores, excluding cabbage, were included in the research (Table 1). Each store sold a different variety of vegetables and herbs which was dependent on supplier and time of the year.

\section{Data collection}

The study extended from January to July 2017. For each of four replicates, the days of the week were allocated at random to each store, in a way that every week the four stores would be visited, each one in a different day of the week, until all stores had been visited one time each day from Monday to Friday. Day of the week was used as a local control because previous interviews with the supermarket staff indicated that the quantity of waste is dependent on day of the week. No store personnel would know in advance the day their store would be visited.

At each evaluation day the following data were collected:

1) Number of produce items received: upon reception at the store, all produce received were counted and expressed as number of units of each vegetable species per supplier per store per day of the week.

2) Visual quality of produce: it was assessed using a 1 to 5 visual scale, developed by the authors, where $5=$ absence of decay, bruises, wilting or yellowing; no trimming necessary; 4= presence of decay, bruises, wilting, or yellowing, combined or isolated, in the outer or lower leaves, which could be easily trimmed while replenishing the shelves, making it a grade 5 quality; $3=$ presence of decay, bruises, wilting or yellowing, combined or isolated, in the outer and inner leaves, requiring extensive trimming to make it into Grade $5 ; 2=$ presence of decay, bruises, wilting or yellowing, combined or isolated, in such scale that after trimming not enough produce was left to sell; $1=$ deteriorated. The number of units 
sampled per produce for visual quality was $1,2,3$ or 4 units, when the number of units purchased was respectively less than 5 units; 5 to 10 units; 10-30 units; more than 30 units. Samples were taken at random, immediately after reception and before display. One single grade was given per produce species. When the appearance was not similar among the units sampled, extra samples were taken until it was possible to establish a grade that best represented the batch. All the units sampled were inspected, photographed and later reunited with the remaining ones and put on sale. Visual quality was expressed as percentage of samples of each produce species in each class per supplier per store per day of the week.

3) Number of produce items discarded: discard of produce no long marketable was made by the supermarket staff, with no interference of the researcher. The produce discarded at the store at each sampling day were counted and expressed as number of units of each produce species per supplier per store per day of the week.

4) Cause of discard: after counting, all discarded produce were classified into 1 of 7 mutually exclusive categories, namely $1=$ wilt; $2=$ yellow; $3=$ decay and/or bruises; $4=$ wilt and yellow; $5=$ wilt and decay and/or bruises; $6=$ yellow and decay and/or bruises; $7=$ wilt and yellow and decay and/or bruises. Decay and/or bruises were combined in the same category because at this stage it was not possible to determine whether pathogens were associated with the bruises, neither if decay, when present, was preceded by bruises. The number of produce discarded in each category was expressed as percentage of the total number of discarded produce per species per supplier per store per day of the week. Counting and analysis of the discarded produce were performed immediately after the culling operation by the store staff.

\section{Flow of work}

The operations in each store, from reception to exposition and culling, were described based on observations and discussion with the store staff directly involved with produce marketing.

\section{Data analysis}

The effect of store, supplier and day of the week on the number of items discarded per day was analysed by means of a covariance analysis. Interactions among store, supplier and day of the week were not studied because not all suppliers were present in all stores. Descriptive measures of central tendency (mean) and variability (coefficient of variation) were computed for the number of produce units purchased and discarded. The frequency of produce in each class of visual quality and the relative importance of each cause of discard compared to the other causes were calculated via Chi-Square test associated with the corresponding contingency table. The results were expressed as the percentage of units discarded in each class in relation to the total number of vegetables discarded. Statistical analyses were carried out using SAS software (V.9.4).

\section{RESULTS AND DISCUSSION}

\section{Work-flow:reception, shelf replenishing and discard of vegetables and herbs}

Leafy vegetables were received daily, except on Sunday, from 5 a.m. to 8 a.m., depending on the store and supplier. Deliver was made by the farmer using its own vehicle to the store or to a distribution center.

In broad terms, the daily workflow of the produce department was the same in all stores: reception; culling (removal and discard of damaged and deteriorated vegetables and herbs from the shelf) a single time in the morning; display of the new produce together with the remaining one from previous days, a single time in the morning. Storage of vegetables and herbs in refrigerated rooms, or in the back rooms, followed by replenishment of displays in the afternoon were very rare.

At reception, the vegetables and herbs from all suppliers would be counted one by one. The reception and conference were done very rapidly, among other reasons because there were usually one or two staff members to receive all the goods delivered to the store. The reception included the transference of goods from the farmer's crates to the supermarket crates, except for Farmer-1. Farmer-1 delivered his produce in the supermarket crates that he had collected the previous day. Lack of care during transfer of the goods was one important source of mechanical damage to the vegetables.

After reception, the crates were stacked in the store marketplace until replenishment. In Store-4, re-stock was done between 6 a.m. and 7 a.m. In the other stores, it was common to have the crates stacked in the area until late in the morning because the staff was involved in other activities. In these stores, customers arriving early in morning would not find fresh produce to buy.

The criteria for discard, that is, which produce was still marketable and which was not, was quite variable depending on the store and on the staff in each store. Except for Store-4, it was common to leave damaged vegetables and herbs on display with the hope they could still be sold. When displaying the new produce, some staff followed the principles of First in-First out, while others would pile the new ones on top of the old ones, which would remain in display until deteriorated.

In Stores-1 and 3, the display was refrigerated for all leafy vegetables and herbs but iceberg lettuce. In Store-2, all vegetables were displayed in non-refrigerated shelves. In Store-4, conventional and hydroponics produce were refrigerated, and organic were not.

Signalling of the vegetables and herbs' price was difficult to read. Identification of each item was available in Farmer-4's package (in the front part of the package in big letters) and in Farmer-3's package (in small letters at the side of the bar code) but not in Farmer-1 and Farmer-2's package. Lack of identification contributed to uncareful manipulation of the packages by the customers looking for the vegetables and herbs they wanted to buy.

In all stores, stack the produce very tightly, was a common practice, what resulted in physical damage, poor aeration of the produce, an unattractive display and difficulty to visualize those sold in small number and/or in smaller packages such as wild chicory, mustard greens, broad-leaved endive, and fresh 
herbs.

Quantity and factors that influence vegetables and herbs discard

The ratio of total number of items discarded to the total number of items purchased in all stores, from all suppliers, in all days sampled varied from about $9 \%$ to $97 \%$ when the raw data were considered (Figure 1). We are aware there is a bias in these numbers since the vegetables and herbs discarded on a given day were not from the same batch purchased in that specific day. That happened because the vegetables discarded at a specific day of evaluation could have been bought one or more days before the day of the sampling. To follow the story of each specific vegetable discarded in the store would require a strenuous work for which there was no labour force available or interference in the way the vegetables are marketed, such as waiting all the old vegetables to be sold before displaying
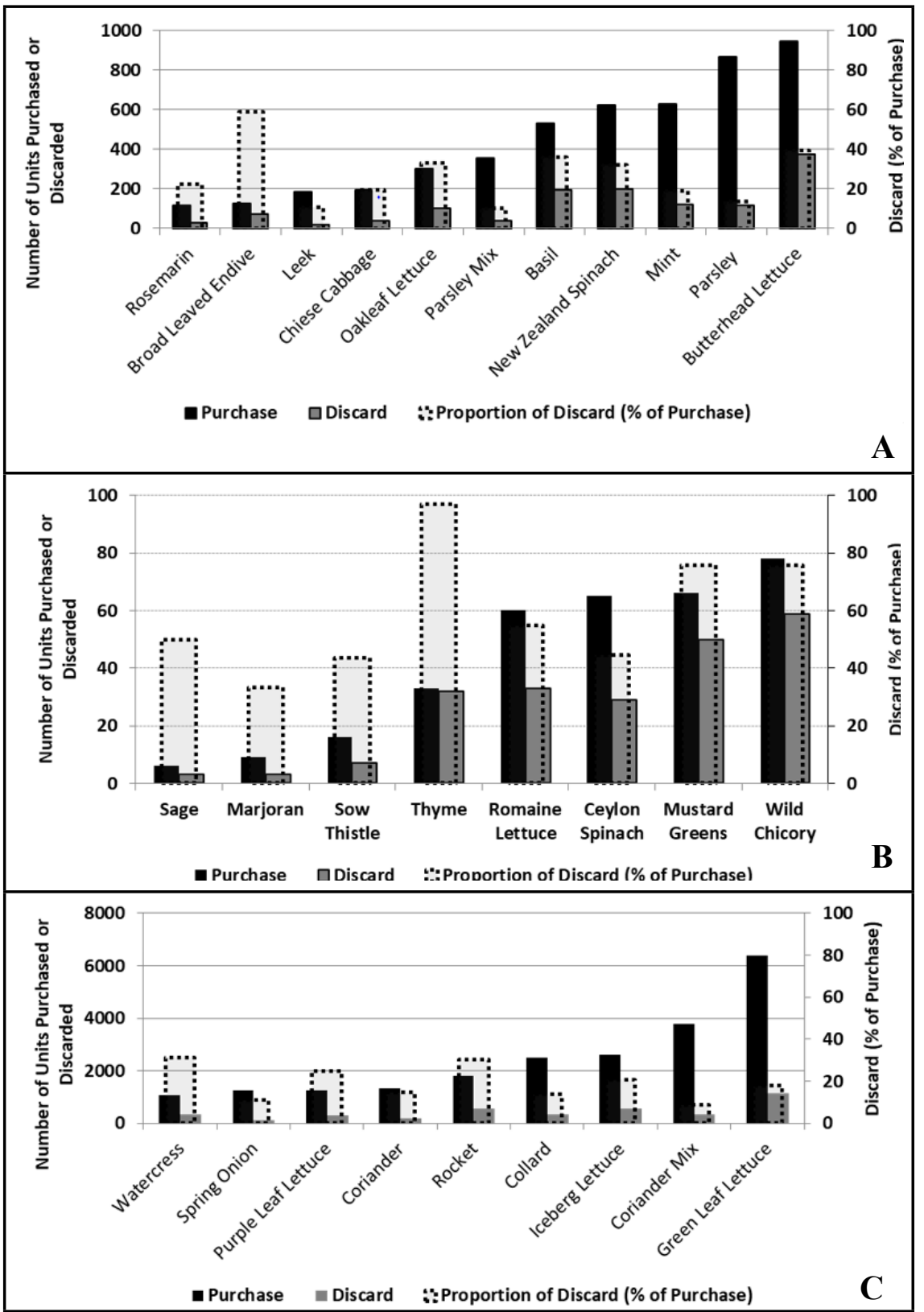

Figure 1. Ratio of total number of vegetable units discarded to the total number of vegetable units purchased (expressed as percentage of number of units). Number of units purchased varied from 6 to 78 (A), 116 to 947 (B) and 1073 to 6385 (C). Data include the sum of all stores, suppliers and days of the week. The number of vegetable units purchased and sold in all days sampled is plotted for comparison. Brasília, Embrapa Hortaliças, 2017.

the new ones. Choice was made to identify the causes for discard in real sale conditions, even if that would imply in a reduction of accuracy in the estimation of the quantity of waste as a ratio of the quantity of purchase.

Waste in the order of $30 \%$ was the most common value observed (Figure 1). This value is in accordance with the average value reported by FAO for food loss and waste in the world but higher than the $12 \%$ fruit and vegetable waste in the distribution step reported for Latin America (FAO, 2011). However, one must keep in mind that FAO results are expressed in mass and ours are expressed in number of units. Smaller waste was observed for produce with higher sales volume such as collard, coriander mix and green leaf lettuce. Waste equal to or above $50 \%$ was observed for produce purchased in small quantity (2 to 5 units/day) and their waste, although proportionally high, is hardly perceived as such by the supermarket staff. They pay much more attention to the waste of collard and lettuce, comprising more units, but which represent a much smaller proportion of the amount purchased.

It is not possible to discuss whether this volume of waste is representative of other market channels since no other data, obtained in the country and using similar methodology, are available for comparison.

Data from other countries in Europe and North America (Buzby et al., 2015; 2016; Eriksson et al., 2012; Gustavsson \& Stage, 2011 Mena et al., 2011) were obtained under conditions so different from that encountered in Brazil that they are hardly comparable. The average supermarket shrink for the different varieties of leafy vegetables ranged from $8.3 \%$ to $62.9 \%$ in USA (Buzby et al., 2016), but in those estimates are included products removed from stores by theft, accounting errors, and other factors besides the operations breakdowns considered in our research. Despite the differences in methodology and the conditions encountered in Brazil and in USA, in both cases there was a large difference in volume waste depending on the vegetable considered. Eriksson et al. (2012) reported pre-store 
Table 1. List of leafy vegetables and fresh herbs analysed. Brasília, Embrapa Hortaliças, 2017.

\begin{tabular}{|c|c|c|}
\hline Scientific name & Commom name in English & Common name in Portuguese \\
\hline \multicolumn{3}{|c|}{ Vegetables } \\
\hline Nasturtium officinale & watercress & agrião \\
\hline Lactuca sativa & iceberg lettuce & alface americana \\
\hline Lactuca sativa & green leaf lettuce & alface crespa \\
\hline Lactuca sativa & butterhead lettuce & alface lisa \\
\hline Lactuca sativa & oakleaf lettuce & alface mimosa \\
\hline Lactuca sativa & purple leaf lettuce & alface roxa \\
\hline Lactuca sativa & baby romaine lettuce & mini alface romana \\
\hline Allium porrum & leek & alho-porró \\
\hline Cichorium intybus & wild chicory & almeirão \\
\hline Basella alba & Ceylon spinach & bertalha \\
\hline Cichorium endivia var. Latifolia & broad-leaved endive & chicória lisa \\
\hline Brassica oleracea var. acephala & collard & couve \\
\hline Brassica pekinensis & Chinese cabbage & couve-chinesa \\
\hline Tetragonia tetragonioides, syn. T. expansa & New Zealand spinach & espinafre da Nova Zelândia \\
\hline Brassica juncea & mustard greens & mostarda de folha \\
\hline Eruca sativa & rocket & rúcula \\
\hline Sonchus oleraceus & common sow thistle & serralha \\
\hline \multicolumn{3}{|c|}{ Herbs } \\
\hline Rosmarinus officinalis & rosemarin & alecrim \\
\hline Allium fistulosum & spring onion & cebolinha \\
\hline Coriandrum sativum & coriander & coentro \\
\hline Petroselinum crispum & parsley & salsa \\
\hline Allium fistulosum + Petroselinum crispum & mixed spring onion and parsley & cheiro verde + salsa \\
\hline Allium fistulosum + Coriandrum sativum & mixed spring onion and coriander & cheiro verde + coentro \\
\hline Mentha spicata & spearmint & hortelã \\
\hline Ocimum basilicum & basil & manjericão \\
\hline Origanum majorana & marjoran & manjerona \\
\hline Thymus vulgaris & thyme & tomilho \\
\hline Salvia officinalis & sage & sálvia \\
\hline
\end{tabular}

Table 2. Average number of units of leafy vegetables and fresh herbs discarded per day, adjusted for quantity purchased. Brasília, Embrapa Hortaliças, 2017.

\begin{tabular}{|c|c|c|c|c|c|}
\hline \multicolumn{2}{|l|}{ Store } & \multicolumn{2}{|c|}{ Supplier } & \multicolumn{2}{|c|}{ Day of the week } \\
\hline Store-1 & $36.7 \mathrm{~A}^{*}$ & Farmer-1 & $54.4 \mathrm{~A}$ & Monday & $40.1 \mathrm{~A}$ \\
\hline Store-2 & $35.4 \mathrm{~A}$ & Farmer-2 & $33.3 \mathrm{~B}$ & Tuesday & $28.3 \mathrm{~B}$ \\
\hline Store-3 & $23.3 \mathrm{~B}$ & Farmer-3 & $19.8 \mathrm{C}$ & Wednesday & $24.4 \mathrm{~B}$ \\
\hline Store-4 & $21.1 \mathrm{~B}$ & Farmer-4 & $10.0 \quad \mathrm{D}$ & Thursday & $23.9 \mathrm{~B}$ \\
\hline & & & & Friday & $30.1 \mathrm{AB}$ \\
\hline
\end{tabular}

*Numbers in the same column followed by same letters do not differ statistically by $\mathrm{t}$ Test (Pr $>0.05)$; Values for store include data of all suppliers and all days of the week. Values for supplier include data of all stores and all days of the week. Values for day of the week include data of all suppliers and all stores. (produce rejected at delivery) and instore (after purchase from the supplier) waste in a Swedish retail chain. Lettuce was the only leafy vegetable reported and its waste in-store was as low as $2.1 \%$ of the mass purchased, a value much lower than those reported in this paper.

When considering the sum of all leafy vegetables and fresh herbs in each store, the discard (expressed as units per day and corrected for quantity purchased), was influenced by all factors studied, namely store ( $\mathrm{Pr}>\mathrm{F}$ 0.0035), supplier ( $\operatorname{Pr}>$ F 0.0003) and day of the 
Table 3. Proportion of produce in each class of visual quality, at reception in the store. Values for store include data of all suppliers and all days of the week. Values for supplier include data of all stores and all days of the week. Brasília, Embrapa Hortaliças, 2017.

\begin{tabular}{lccccc}
\hline & \multicolumn{5}{c}{ By store } \\
\hline & Grade 1 & Grade 2 & Grade 3 & Grade 4 & Grade 5 \\
\cline { 2 - 6 } & 0.3 & 6.1 & 15.6 & 36.4 & 41.7 \\
\hline Store-1 & 0.0 & 1.1 & 10.6 & 49.7 & 38.6 \\
Store-2 & 0.5 & 5.7 & 18.6 & 43.4 & 31.8 \\
Store-3 & 0.4 & 4.5 & 15.4 & 42.7 & 37.1 \\
Store-4 & 0.0 & 1.3 & 14.4 & 49.1 & 35.3 \\
\hline \multicolumn{5}{c}{ By supplier } \\
\hline Farmer-1 & 0.6 & 8.2 & 22.2 & 40.0 & 29.1 \\
Farmer-2 & 0.0 & 1.4 & 7.9 & 48.1 & 42.6 \\
Farmer-3 & 0.0 & 0.0 & 2.9 & 31.8 & 65.3 \\
Farmer-4 & \multicolumn{5}{c}{ Total } \\
\hline \multicolumn{7}{c}{ All stores and } & 0.28 & 4.28 & 14.77 & 42.80 & 37.87 \\
suppliers & &
\end{tabular}

Grade 5= absence of decay, bruises, wilting or yellowing; no trimming necessary; Grade 4= presence of decay, bruises, wilting, or yellowing, combined or isolated, in the outer or lower leaves; light trimming make it a grade 5 quality; Grade $3=$ presence of decay, bruises, wilting or yellowing, combined or isolated, in the outer and inner leaves; extensive trimming make it a grade 5 quality; Grade $2=$ presence of decay, bruises, wilting or yellowing, combined or isolated, in such scale that after trimming not enough vegetable was left to sell; Grade $1=$ deteriorated.

week $(\mathrm{Pr}>\mathrm{F}$ 0.0160) (Table 2).

The amount of waste was corrected for the amount purchased by means of a co-variance analysis so that the effect of store and supplier would not be influenced by the amount of purchase in each case. The effect of store was in part confounded by the effect of supplier but differences in workflow, management and display in each store also accounted for the differences observed. Likewise, the effect of supplier was partially confounded by store in the case of Farmer-1, since this supplier was present in one single store. Retail chains commonly have the strategy of diversifying their range of suppliers and the quantity and variety of produce will depend on the location of the store. This was the situation in the retail chain studied here what prevented the possibility of studying the same group of suppliers and range of produce in all stores to have a full factorial design and a better estimation of the effects of store, supplier and their interaction.

Differences among suppliers were in the magnitude of 5 times, when the highest and the smallest values of discard were compared. A similar comparison among stores was in the magnitude of 2 times. When the vegetables were analysed individually, again supplier was the main source of variation (data not shown). However, its effect could not be estimated for all species, since some of them were bought from a single supplier in each store.

The quantity of waste in Stores 3 and 4 did not differ significantly, although conditions in both stores were quite diverse. In Store-4, handling was more careful, the display was more attractive and stock control was better compared with the others. In Store-3, vegetables long passed the minimum quality for consumption would stay on display for days, giving a false impression of low waste volume, until they were deteriorated. Stores- 1 and 2 did not differ significantly in the waste volume, but again had different reasons for the same amount of waste. Delays to display the produce, very unattractive display and careless handling were frequent in Store-1. In Store-2 the more careful handling and more attractive display were offset by lack of refrigeration, delay to expose the produce and very poor stock control in the first half period of the research.

Differences among farmers are the result of a number of factors including those considered here (visual quality, packaging, mix of produce) and those not considered here (cultivar, production practices, handling in the farm and during transport, temperature and air humidity from farm to store). This clearly brings a limitation on how far it is possible to analyse the farmer's effect. However, even with those limitations, it was possible to identify some reasons for differences among suppliers. The differences in waste volume from Farmers-2, 3 and 4 were in part the result of the quality of the vegetables supplied by each of them as it will be discussed further. Other reason that may have contributed to differences among suppliers is the range of produce they sell to the supermarket. Farmer-4 supplies only those vegetables that have a higher inventory turnover and consequently are less wasted. Farmers- 1 and 2, on the other hand, offer 21 different varieties including those less consumed and more likely to end as waste as it will be discussed further. Besides that, the effect of supplier is the result of the effect of the quality of his produce plus the potential shelf life of the species he delivers. For example, Chinese cabbage is much more resistant to handling than lettuce, collard is much more resistant to wilting than wild chicory, and spinach is much more resistant to yellowing than spring onion.

Higher volumes of waste were observed on Mondays and Fridays, confirming the need to allocate day of the week as a local control, so that the same number of samples are obtained for each day of the week. On Monday, culling is more rigorous due to absence of culling on Sunday and cleaning of the displays on Monday. On Friday, it was probably the result of poor stock control on the purchase for Wednesday, the promotion day in this chain, when most fruits and vegetables are sold at lower price, but this hypothesis needs further investigation.

\section{Variability in the volume of purchase and discard}

The quantity of each vegetable species purchased and discarded per day, 
when data from all stores, suppliers and days of the week were combined, was quite variable.

The coefficient of variation of the number of units purchased per day ranged from $69.4 \%$ to $565.6 \%$ depending on the vegetable or herb (data not shown). Reasons for variation in the quantity purchase may lie in the supply side (farmer) and in the demand side (store) but were not investigated in the present research.

The quantity of units discarded per day was also quite variable and the coefficient of variation ranged from $158.07 \%$ to $632.14 \%$ depending on the vegetable or herb considered (data not shown). The large variability in the quantity of discard was partly due to the variability in supply. However, it was, in great measure, the result of the way the staff in each store restocked the produce display. It was common practice, especially in Stores-1 and 3, to leave damaged produce on display until they deteriorated. This means that a typical situation would be, for example, to have no discard of a specific vegetable on Monday and Tuesday, followed by discard on Wednesday of units of that same vegetable which had been purchased from Saturday to Tuesday. The absence of discard could be because that item was not on display (sold out or not purchased); because the item on

Table 4. Proportion of produce in each class of visual quality at reception in the store (\%). Values for produce include data of all stores, suppliers and days of the week. Brasília, Embrapa Hortaliças, 2017.

\begin{tabular}{|c|c|c|c|c|c|}
\hline Vegetable & $\begin{array}{c}\text { Grade } \\
1\end{array}$ & $\begin{array}{c}\text { Grade } \\
2\end{array}$ & $\begin{array}{c}\text { Grade } \\
\mathbf{3}\end{array}$ & $\begin{array}{c}\text { Grade } \\
4\end{array}$ & $\begin{array}{c}\text { Grade } \\
5\end{array}$ \\
\hline Watercress & 0.00 & 3.54 & 21.4 & 50.44 & 24.78 \\
\hline Iceberg lettuce & 0.00 & 2.67 & 10.0 & 30.67 & 56.67 \\
\hline Green leaf lettuce & 0.00 & 0.56 & 14.53 & 55.31 & 29.61 \\
\hline Butterhead lettuce & 0.95 & 7.62 & 35.24 & 50.48 & 5.71 \\
\hline Oakleaf lettuce & 0.00 & 2.86 & 0.00 & 60.00 & 37.14 \\
\hline Purple leaf lettuce & 0.00 & 0.79 & 7.09 & 66.14 & 25.98 \\
\hline Baby romaine lettuce & 0.00 & 0.00 & 0.00 & 20.00 & 80.00 \\
\hline Leek & 0.00 & 0.00 & 5.36 & 44.64 & 56.00 \\
\hline Wild chicory & 0.00 & 16.67 & 55.56 & 25.00 & 2.78 \\
\hline Ceylon spinach & 0.00 & 0.00 & 6.25 & 31.25 & 62.5 \\
\hline Broad-leaved endive & 0.00 & 0.00 & 6.98 & 69.77 & 23.26 \\
\hline Collard & 0.00 & 4.00 & 10.00 & 26.67 & 59.33 \\
\hline Chinese cabbage & 0.00 & 0.00 & 4.82 & 32.53 & 62.65 \\
\hline New Zealand spinach & 0.00 & 0.86 & 14.66 & 59.48 & 25.00 \\
\hline Mustard greens & 3.13 & 37.50 & 46.88 & 12.50 & 0.00 \\
\hline Rocket & 1.76 & 18.24 & 25.88 & 34.71 & 19.41 \\
\hline Common sow thistle & 11.11 & 33.33 & 0.00 & 22.22 & 33.33 \\
\hline Rosemarin & 0.00 & 0.00 & 0.00 & 0.00 & 100.00 \\
\hline Spring onion & 0.00 & 0.00 & 7.41 & 34.07 & 58.52 \\
\hline Coriander & 0.00 & 2.84 & 10.64 & 53.90 & 32.62 \\
\hline Parsley & 0.00 & 1.05 & 3.16 & 29.47 & 66.32 \\
\hline Spring onion and coriander mix & 0.00 & 3.85 & 17.31 & 54.81 & 24.04 \\
\hline Spring onion and parsley mix & 0.00 & 2.17 & 4.35 & 34.78 & 58.70 \\
\hline Spearmint & 0.00 & 4.23 & 39.44 & 49.30 & 7.04 \\
\hline Basil & 0.00 & 1.33 & 9.33 & 30.67 & 58.67 \\
\hline Marjoran & 0.00 & 0.00 & 0.00 & 0.00 & 100.00 \\
\hline Sage & 0.00 & 0.00 & 0.00 & 33.33 & 66.67 \\
\hline
\end{tabular}

Table 5. Cause of vegetable discard (\%). Brasília, Embrapa Hortaliças, 2017.

\begin{tabular}{|c|c|c|c|c|c|c|c|}
\hline & Yellow & Wilt & $\begin{array}{l}\text { Bruised/ } \\
\text { decayed }\end{array}$ & $\begin{array}{c}\text { Yellow }+ \\
\text { wilt }\end{array}$ & $\begin{array}{c}\text { Yellow + bruised/ } \\
\text { decayed }\end{array}$ & $\begin{array}{c}\text { Wilt + bruised } / \\
\text { decayed }\end{array}$ & $\begin{array}{c}\text { Yellow }+ \text { wilt }+ \\
\text { bruised/decayed }\end{array}$ \\
\hline \multicolumn{8}{|c|}{ By store } \\
\hline Store-1 & 0.88 & 12.02 & 22.77 & 3.58 & 5.84 & 31.42 & 23.48 \\
\hline Store-2 & 0.19 & 8.90 & 9.56 & 4.33 & 3.82 & 26.38 & 46.82 \\
\hline Store-3 & 0.42 & 9.58 & 6.67 & 2.78 & 4.86 & 44.58 & 31.11 \\
\hline Store-4 & 3.54 & 15.56 & 15.13 & 2.12 & 4.95 & 42.01 & 16.69 \\
\hline \multicolumn{8}{|c|}{ By supplier } \\
\hline Farmer-1 & 0.22 & 10.19 & 8.97 & 4.16 & 5.03 & 21.75 & 49.68 \\
\hline Farmer-2 & 1.22 & 11.46 & 17.86 & 1.44 & 6.99 & 39.11 & 21.92 \\
\hline Farmer-3 & 1.27 & 9.88 & 10.93 & 5.24 & 2.32 & 31.96 & 38.40 \\
\hline Farmer-4 & 0.25 & 16.46 & 25.55 & 7.86 & 0.25 & 32.19 & 17.44 \\
\hline \multicolumn{8}{|c|}{ Total } \\
\hline $\begin{array}{l}\text { All farmers } \\
\text { and suppliers }\end{array}$ & 0.89 & 10.92 & 14.37 & 3.58 & 4.79 & 32.59 & 32.85 \\
\hline
\end{tabular}

Each value is the percentage in relation to the total of the line. Values for store include data of all suppliers, produce and days of the week. Values for supplier include data of all stores, produce and days of the week. 
Table 6. Cause of vegetable and fresh herb discard (\%). Brasília, Embrapa Hortaliças, 2017.

\begin{tabular}{|c|c|c|c|c|c|c|c|}
\hline Produce & Yellow & Wilt & $\begin{array}{c}\text { Bruised / } \\
\text { decayed }\end{array}$ & $\begin{array}{c}\text { Yellow + } \\
\text { wilt }\end{array}$ & $\begin{array}{c}\text { Yellow + bruised/ } \\
\text { decayed }\end{array}$ & $\begin{array}{c}\text { Wilt + bruised } / \\
\text { decayed }\end{array}$ & $\begin{array}{c}\text { Yellow }+ \text { wilt }+ \\
\text { bruised/decayed }\end{array}$ \\
\hline Watercress & 0.00 & 10.18 & 5.09 & 4.49 & 1.80 & 12.57 & 65.87 \\
\hline Iceberg lettuce & 0.00 & 7.54 & 38.88 & 0.00 & 0.77 & 48.16 & 4.64 \\
\hline Green leaf lettuce & 0.00 & 7.68 & 20.65 & 1.15 & 3.71 & 32.39 & 34.42 \\
\hline Butterhead lettuce & 0.00 & 1.08 & 20.97 & 1.34 & 9.68 & 21.24 & 45.70 \\
\hline Oakleaf lettuce & 0.00 & 1.00 & 30.00 & 0.00 & 9.00 & 43.00 & 17.00 \\
\hline Purple leaf lettuce & 0.00 & 12.70 & 16.19 & 0.00 & 0.00 & 69.21 & 1.90 \\
\hline Baby romaine lettuce & 0.00 & 9.09 & 27.27 & 0.00 & 3.03 & 51.52 & 9.09 \\
\hline Leek & 7.14 & 0.00 & 50.00 & 21.43 & 14.29 & 0.00 & 7.14 \\
\hline Wild chicory & 0.00 & 6.78 & 16.95 & 3.39 & 3.39 & 54.24 & 15.25 \\
\hline Ceylon spinach & 0.00 & 51.72 & 0.00 & 3.45 & 0.00 & 31.03 & 13.79 \\
\hline Broad-leaved endive & 0.00 & 10.96 & 13.70 & 0.00 & 13.70 & 16.44 & 45.21 \\
\hline Collard & 6.30 & 3.44 & 3.44 & 16.05 & 28.94 & 3.15 & 38.68 \\
\hline Chinese cabbage & 2.63 & 21.05 & 18.42 & 10.53 & 0.00 & 18.42 & 28.95 \\
\hline New Zealand spinach & 0.00 & 14.50 & 4.00 & 0.00 & 0.00 & 79.50 & 2.00 \\
\hline Mustard greens & 0.00 & 14.00 & 10.00 & 6.00 & 0.00 & 38.00 & 32.00 \\
\hline Rocket & 0.00 & 5.42 & 3.07 & 2.89 & 0.90 & 29.48 & 58.23 \\
\hline Common sow thistle & 0.00 & 71.43 & 0.00 & 0.00 & 0.00 & 28.57 & 0.00 \\
\hline Rosemarin & 0.00 & 100.00 & 0.00 & 0.00 & 0.00 & 0.00 & 0.00 \\
\hline Spring onion & 12.95 & 2.16 & 0.72 & 15.11 & 16.55 & 1.44 & 51.08 \\
\hline Coriander & 0.00 & 5.64 & 10.77 & 4.10 & 1.03 & 51.79 & 26.67 \\
\hline Parsley & 0.00 & 42.45 & 2.83 & 25.47 & 2.83 & 14.15 & 12.26 \\
\hline Spring onion + coriander & 0.00 & 0.60 & 7.85 & 5.14 & 1.81 & 14.20 & 70.39 \\
\hline Spring onion + parsley & 16.67 & 13.89 & 0.00 & 0.00 & 2.78 & 5.56 & 61.11 \\
\hline Spearmint & 0.00 & 5.83 & 15.83 & 0.83 & 3.33 & 73.33 & 0.83 \\
\hline Basil & 0.00 & 72.04 & 2.69 & 0.00 & 0.00 & 22.58 & 2.69 \\
\hline Marjoran & 0.00 & 100.00 & 0.00 & 0.00 & 0.00 & 0.00 & 0.00 \\
\hline Thyme & 0.00 & 93.75 & 0.00 & 0.00 & 0.00 & 6.25 & 0.00 \\
\hline Sage & 0.00 & 100.00 & 0.00 & 0.00 & 0.00 & 0.00 & 0.00 \\
\hline
\end{tabular}

Each value is the percentage in relation to the total of the line. Values for each produce include data from all suppliers, stores and days of the week.

display was in good condition for sale or because the item, not good enough to sell, was kept on display instead of being discarded.

Other factors besides supplier, store and day of the week influenced the quantity of waste. These other factors were not considered in the statistical model because they were not known at the beginning of the research and their estimation would require an experimental design different from the one used.

The first of these factors is the item considered. When the same analysis of covariance made for the sum of all vegetables and herbs was performed for each one of them individually, the model was valid for 17 out of 26 (for $\operatorname{Pr}>\mathrm{F}<0.0500)$ and the effects of store, supplier and day of the week were not equally significant for all items.

The second important factor that influenced the quantity of waste is the staff member in charge of replenishing the shelves. The difference between staff members was notorious and its effect occurred in different ways: determining which vegetables were discarded, the amount of manipulation, how careful was the handling and how attractive was the display. This effect would have been included in the effect of store were the staff members the same in each store during the time span of the research. However, there were frequent changes in personnel and differences in the work flow of a single staff due to last minute assignments of more urgent tasks by the manager. At the same time, most of the knowledge this staff had on consumer preference was hardly considered by the person in charge of ordering merchandise and checking quality at reception. A better management of order size and variety is one of the strategies to reduce food waste at the retail market.

\section{Visual quality at reception}

Delivery of produce with any signs of wilting and yellowing was negligible. Grades lower than 5 were almost always due to bruises and darkening of the damaged tissues and/or the presence of damaged and old leaves which should 
have been trimmed in the farm. The frequency of vegetables in each class of visual quality was dependent on store (chi square value $=53.27 ; \mathrm{P}<0.0001$ ) and on supplier (chi square value $=$ 293.35; $\mathrm{P}<0.0001$ ) but not on day of the week (chi square value $=19.09 ; \mathrm{P}=$ 0.2637).

Differences among stores (Table 3) were probably more related to different suppliers delivering in each store, than to the same supplier delivering produce with different quality to different stores.

Hydroponic produce, supplied by Farmer-4, was the one with better visual quality and more than half of it was graded 5 (Table 3). Occasionally it would be graded 4 due to the presence of old leaves which were not trimmed (watercress, rocket and green leaf lettuce) or the presence of split rib in iceberg lettuce. Very rarely it would be graded 3.

In general, produce from Farmer-2 was the one with lower visual quality and less than $30 \%$ of his delivery was graded 5. Low visual quality was due to insufficient trimming, crushed tissue due to careless tie of the bunch and excess of produce in the crates. The produce was delivered very wet and packed in plastic bags too small, causing extra damage to the leaves. Transference to the supermarket crates during reception was made without care and would further damage the produce.

Produce from Farmers- 1 and 3 were of intermediary quality compared with the other two suppliers. Less than $1.5 \%$ of their produce was graded 2 and about $50 \%$ was graded 5 . The visible improvement in Farmer-1's vegetable visual quality during the research was not always followed by reduction in waste because it was not paralleled by a better stock control, neither by improvements in display.

When data from all stores and suppliers were pooled, clear differences were observed among the vegetables and herbs (Table 4). Higher frequency of damaged units (grades 1 and 2) was observed for common sow thistle, mustard greens, wild chicory, rocket and butterhead lettuce. Higher frequency of units without damage was observed for rosemarin, marjoram, sage, parsley, spring onion, baby romaine lettuce, leek, Chinese cabbage and iceberg lettuce.

\section{Cause of discard}

The rapid decrease in visual quality, together with the practice of leaving partially damaged produce on display, resulted in the produce being discarded only when they were improper for consumption, mostly with a combination of more than one kind of damage. This is quite different from the situation discussed by Cicatiello et al. (2017) and Porat et al. (2018) where food waste, taking place in retail and consumption, results in discarding of food that still contains adequate nutritional value and that could have been consumed through redistribution for people in need or sold at a lower price.

The discard of leafy vegetables and herbs happened when the leaves were wilt, yellow or bruised/decayed. These damages could occur isolated or combined, being the last one the most frequent situation. Bruise/decay, either as a single cause or combined with wilting and yellowing, was the cause of discard of more than $80 \%$ of the samples. The main cause for discard, when all vegetables were considered together, was dependent of store (chi square value $=572.6 \mathrm{P}<$ 0.0001 ), supplier (chi square value $=$ $557.7 \mathrm{P}<0.0001)$ and day of the week (chi square value $=164.0 \mathrm{P}<0.0001$ ). Except for Farmer-4, the combinations yellow-wilt-bruised/decayed and wiltbruised/decayed were the main causes of discard. Which one was more important was dependent on the store, supplier and day of the week (Table 5).

When each vegetable or herb was analysed separately, grouping the data for supplier, store and day of the week, the most frequent cause of discard depended on the item considered (chi square value $=4927.3 \mathrm{P}<0.0001)($ Table $6)$. From the 28 items analysed, yellowwilt-bruised/decayed was the first cause of discard of 9 items, followed by wiltbruised/decayed (9 items) and wilt (7 items).

Since vegetables partially damaged were sold, it is expected that part of the discard that would happen in the store, if only vegetables graded 5 were sold, was transferred to the consumer. In this case, the household vegetable waste will consist of inedible parts (wilt, yellow, bruised and decayed) that deteriorated due to improper postharvest handling in the supply chain, starting at harvest, and not due to negligence of the consumer. It remains to be answered whether the discard on household is expressive, and what are the financial costs for the consumer and for the municipality that must collect and process the waste.

Relation between visual quality at reception and discard

A high proportion of vegetables graded 4 and 5 at reception seems to be at odds with the high volume of waste in the stores and with the high proportion of bruised/decayed produce discarded. A few factors explain this apparent contradiction.

Visual quality is important to determine shelf life and preference by the consumer but how important it was, depended on other factors such as the item considered and the workflow in the store. Here we hypothesise a scenario for further investigation. There are many more regular consumers of green leaf lettuce and spring onion-coriander mix than of New Zealand spinach and watercress, for example. When green leaf lettuce and spring onion-coriander mix had low visual quality they are purchased anyway, even knowing that part of it will be wasted at home. The same does not happen with New Zealand spinach and watercress, where impulse purchase is more likely to occur when they are attractive, and no purchase is more likely to occur when they have low quality. For a third group of produce, such as wild chicory, ceylon spinach and mustard greens, a good visual quality is not enough to induce sale, since many costumers do not know how to prepare them, and the staff was not able to provide information on that when consulted by costumers. A general lack of consumer knowledge about their preparation was also considered one of the causes of the high shrinkage of mustard and turnip greens in the retail market in the USA (Buzby et al., 2016). On the other hand, delays in displaying the produce and a display that hides the produce likely cancelled the effect that a good visual quality could have had 
in increasing sale and reducing waste. This situation was very common in the stores studied.

Other important reason is related to the progress of the visual quality evaluated at reception during commercialization. From the quality aspects evaluated, namely wilt, yellowing and bruise/ decay only the last one, with few exceptions, would be present when the produce was delivered at the store. At this stage, typically less than 1 day after harvest, bruise/decay would be small or localized in outer or lower leaves and the effects of high temperature and low humidity during harvest and transport were still not visible, what resulted in produce being graded 5 or 4 in the scale used here. However, the combination of inadequate display, lack of refrigeration and careless handling by the supermarket staff and by costumers would accelerate all the processes that lead to waste. Later in the day, or in the next day, all the bad practices to which the produce had been subjected would be visible.

In the particular case of Farmer-4, another reason was observed. His produce, crispier and less sturdy than the produce of the others, was more susceptible to physical damage and more likely to be damaged by the rough handling during commercialization by both the store staff and by the customers.

All the failures related with the handling of the produce as much as the improper management practices in the store points to the responsibilities of the retail in the volume of discard observed. They add to the problems arising from the farm due to rough handling and exposure of the produce to inadequate conditions of temperature and humidity. The relative importance of each of them was not quantified here. That is important not only to identify critical points of control, but also because it shows the need to discuss the discount policy between retail and supplier. The supermarkets adopt different policies to charge the supplier for the discard they have, such as a standard discount, bonus or consignment sale as if the supplier were the only actor responsible for that discard. We showed this is not the case.

In view of what is reported here, the definition of food loss as not intentional food discard at production, postharvest and processing stages in opposition to food waste as intentional food discard at retail and consumption stages (Gustavsson et al., 2013) is unsuitable to describe what happens in the Brazilian vegetable supply chain. The understanding of food waste as happening as the result of behaviour in opposition to food loss happening because of technological constraints is a derivation of that concept that in our view is equally unsuitable. Vegetable discard in the Brazilian retail market is in great measure the result of technological constraints and are not intentional, happening when the produce is no longer proper for consumption.

In conclusion, the discard of leafy vegetables and fresh herbs was shown to vary from around 10 to $90 \%$ of the quantity purchased, indicating that in an upper middle-income country as Brazil, food discard at retail level can be very high. The large variation in the volume of discard was due to differences among the produce, the store and the supplier considered.

Reduction of waste under the conditions described here will require several actions at farm and at retail level. For all produce, less and more careful handling is mandatory. To achieve this, both technological and behavioural changes are necessary to improve the way the produce are prepared for market in the farm, transported, received and checked for quality at the store, displayed and purchased by the consumer. For vegetables other than lettuce, collard, spring onion, coriander and their mix, produce merchandising techniques are also necessary since an important part of waste seems to happen because few customers have the habit of eating them or even know how to prepare them. For all produce a better stock control by the store is equally mandatory.

In view of the issues raised by this study, the following questions remain unanswered and are outlined as subject for further studies: 1) what is the extent and cause of discard of leafy vegetables and fresh herbs at other retail equipment such as mixed wholesale-retail store, specialized fresh fruit and vegetables store, street market and other supermarket chains 2) what is the relative importance of managerial routines in the store compared to the handling of the produce in the farm as causes of produce discard in the store; 3 ) what is the extent of discard taking place at consumers home due to purchase of partially damaged vegetables and herbs.

\section{ACKNOWLEDGEMENTS}

The authors are thankful to Brazilian Agricultural Research Corporation for funding this research.

\section{REFERENCES}

BARTZ, JA; BRECHT, JK (eds). 2003. Postharvest physiology and pathology of vegetables. 2 ed. New York: Marcel Dekker Inc. $733 \mathrm{p}$.

BRASIL, 2006. Guia alimentar para a população brasileira - promovendo a alimentação saudável. Ministério da Saúde, Secretaria de Atenção à Saúde, Coordenação Geral da Política de Alimentação e Nutrição, Brasília.158p.

BUZBY, JC; BENTLEY, JT; PADERA, B; AMMON, C; CAMPUZANO, J. 2015. Estimated fresh produce shrink and food loss in U.S. supermarkets. Agriculture 5: 626-648.

BUZBY, JC; BENTLEY, JT; PADERA, B; CAMPUZANO, J; AMMON, C. 2016. Updated supermarket shrink estimates for fresh foods and their implications for ERS loss-adjusted food availability data. USDA. p.40.

CICATIELLO, C; FRANCO, S; PANCINO, B; BLASI, E; FALASCONI, L. 2017. The dark side of retail food waste: Evidences from in-store data. Resources, Conservation and Recycling 125: 273-281.

ERIKSSON, M; STRID, I; HANSSON, PA. 2012. Food losses in six Swedish retail stores: Wastage of fruit and vegetables in relation to quantities delivered. Resources, Conservation and Recycling 68, 14-20.

FAO, 2011. Global food losses and food waste extent, causes and prevention. Rome: FAO. $38 \mathrm{p}$.

FARINA, EMMQ; 2002. Consolidation, multinationalisation, and competition in Brazil: Impacts on horticulture and dairy products systems. Development Policy Review 20: 441-457.

GUSTAVSSON, J; CEDERBERG, C; SONESSON, U. 2013. The methodology of the FAO study: "Global food losses and food waste-extent, causes and prevention"- FAO, 201. SIK Report n. 857. 70p.

GUSTAVSSON, J; STAGE, J. 2011. Retail 
waste of horticultural products in Sweden. Resources, Conservation and Recycling 55: 554-556.

LANA, MM. 2018. Perdas e desperdício de hortaliças no Brasil. In: Perdas e desperdício de alimentos: estratégias para redução. Brasília, DF: Câmara dos Deputados, Edições Câmara, 2018. p.87-114. (Cadernos de trabalhos e debates, 3).

MAINVILLE, DY; REARDON, T. 2007. Supermarket market-channel participation and technology decisions of horticultural producers in Brazil. Revista de Economia e Sociologia Rural 45: 705-727.

MENA, C; ADENSO-DIAZ, B; YURT, O. 2011. The causes of food waste in the supplierretailer interface: Evidences from the UK and Spain. Resources, Conservation and Recycling 55: 648-658.

PORAT, R; LICHTER, A; TERRY, LA; HARKER, R; BUZBY, J. 2018. Postharvest losses of fruit and vegetables during retail and in consumers' homes: Quantifications, causes, and means of prevention. Postharvest Biology and Technology 139: 135-149.

WORLD bank country and lending groups World bank data help desk. Washington. Available: < https://datahelpdesk.worldbank. org/knowledgebase/articles/906519-worldbank-country-and-lending-groups $>$ Acessed Febtuary 8, 2018. 